\title{
EFFECT OF ENDOMYCORRHIZAL FUNGI ON MAIZE PLANTS UNDER DIFFERENT LEVELS OF SALINITY Aboul-Nasr. Amal ${ }^{1}$ and A. Amrir ${ }^{2}$ \\ ${ }^{1}$ Agric. Botany Dept., Fac. Agric., Saba- Basha, Alex. Univ.,Egypt \\ E-mail address: a.aboulnasr@gmail.com \\ ${ }^{2}$ Dept. Soil and Soil Reclamation, Fac. Agric., Al Fourat Univ., Syria
}

\begin{abstract}
A greenhouse experiment was conducted to study the effect of two isolates of arbuscular mycorrhizal fungus (G3 and G4, Glomus intraradices ) on the maize (Zea mays L.) growth, $\mathrm{Na}$ and some nutrients uptake in shoots, and roots content of salicylic acid, proline, arginine, phenylalanine and soluble sugar under $\mathrm{Na} \mathrm{Cl}$ stress. Plants were subjected to four levels of salt stress $\left(0.4,2.0,4.0\right.$ and $\left.6.0 \mathrm{dSm}^{-1}\right)$, one week after germination.

Mycorrhizal inoculation significantly reduced $\mathrm{Na}$ uptake in maize shoots. AMF treatments significantly increased salicylic acid content in roots (G3: 66.7 and 95.6\%) and (G4: 17.4 and $50.4 \%$ ) under 4.0 and $6.0 \mathrm{dSm}^{-1}$, respectively, more than the noninoculated ones at the end of the experiment. Proline and soluble sugar contents in roots showed pronounced increases. $N$ and $P$ uptake in $A M$ shoots significantly increased under salt stress, as compared to the non-inoculated plants. Results conclusively indicate that mycorrhizal inoculation increased the salt stress tolerance of maize plants.
\end{abstract}

Keywords: Arbuscular mycorrhizal fungi; salicylic acid; salt stress; maize

\section{INTRODUCTION}

Salinization of soil is a serious problem and is increasing steadily in many parts of the world, in particular in arid and semi-arid areas (Al-Karaki 2006). Saline soils occupy $7 \%$ of the earth's land surface (Ruiz-lozano et al. 2001) and increased Stalinization of arable land will result in to $50 \%$ land loss by the middle of the $21^{\text {st }}$ century (Wang et al. 2003). High levels of salinity (> $4 \mathrm{dSm}^{-1}$ or $>0.1 \%$ soil content; Juniper and Abbott 1993) in soils is mainly due to the soluble salts in irrigation water and fertilizers used in agriculture (Copeman et al.1996; Al-Karaki 2000), low precipitation and high temperature in these regions and over- exploitation of available water resources (e.g. ground water) (Mouk and Ishii 2006). The direct effects of salt on plant growth may involve : (a) reduction in the osmotic potential of the soil solution that reduces the amount of water available to the plant causing physiological drought (Jahromi et al. 2008); (b) toxicity of excessive $\mathrm{Na}^{-}$and $\mathrm{Cl}^{-}$ions towards the cell - the toxic effects include disruption to the structure of enzymes and other macromolecules, damage to cell organelles and plasma membrane, disruption of photosynthesis, respiration and protein synthesis (Feng et al. 2002); and (c) nutrient imbalance in the plant caused by nutrient uptake and/or transport to the shoot leading to ion deficiencies (Adiku et al. 2001). 
Some microorganisms, particularly beneficial bacteria and fungi can improve plant performance under stress environments and, consequently, enhance yield (Creus et al. 1998). Arbuscular mycorrhizal fungi (AMF) are associated with the roots of over $80 \%$ terrestrial plant species (Smith and Read 1997). AMF have been shown to promote plant growth and salinity tolerance by many researchers. They promote salinity tolerance by employing various mechanisms, such as enhancing nutrient acquisition (Al-Karaki and Al-Raddad 1997), producing plant growth hormones, improving rhizospheric and soil conditions(Lindermann 1994), altering the physiological and biochemical properties of the host (Smith and Read 1995) and defending roots against soil-borne pathogens (Dehne 1982).

Salicylic acid (SA) is widely distributed in monocot and dicot plants. Recent studies show that SA can enhance plant resistance to environmental stresses, such as heat, chilling and drought (Janda et al. 1999; Tissa et al. 2000). Salicylic acid is a plant phenol, and today it is in use as internal regular hormone (Shahba et al. 2010).

This research studies the effect of AMF (Glomus intrardices) on the growth, salicylic acid and chemical contents of maize plants under salinity stress $(\mathrm{NaCl})$.

\section{MATERIALS AND METHODS}

The experiment was carried out in the greenhouse of the faculty of Agriculture, Saba - Basha, Alexandria University, Egypt, during the autumn of 2010 with natural light at 30/20 degrees centigrade (day / night). Two mycorrhizal strains Glomus intrardices were used in this experiment. The first (G3) was isolated from the Experimental Station of Alexandria University at Abies (Aboul - Nasr 1993a), and the second (G4) was produced by " Amykor Company, Germany. The inoculum concists of expanded clay aggregates (2$4 \mathrm{~mm}$ in diameter, leca), containing chlamydospores and fungus mycelium, which had been produced on Tagetes erecta L. (Aboul - Nasr 2004). The inoculum was applied prior to sowing by mixing the carrier material with the substrate $(10 \%, v$.), the controls received the same amount of heat sterilized expanded clay.

A mixture of sterilized sand and peat moss $\left(45 \%: 45 \%, v\right.$.) at $110^{\circ} \mathrm{C}$ for 24 $\mathrm{hr}$ were used as a substrate (mixture $\mathrm{pH}=7.4$ ). Three grains of maize (Zea mays. L.) var. Giza 321, were sown in plastic pots, $(11 \mathrm{~cm}$ in diameter). Seedlings were irrigated with tap water as needed prior to stress applications. Salinity treatments were started, one week after germination. Four levels of $\mathrm{NaCl}$ solution were applied; irrigated with tap water $\left(0.4 \mathrm{dSm}^{-1}\right.$ control), 2,4 and $6 \mathrm{dSm}^{-1}$ of $\mathrm{Na} \mathrm{Cl}$ solution. Plants were irrigated as needed with field capacity, Ca 70\%. Liquid soil fertilizer "Super grow (Agrico., Egypt, 100g /200L), N:P:K = 20:20:20 ) was used and the plants received $30 \mathrm{ml} /$ pot weekly. After 4 and 8 weeks from the beginning of salt treatments, i.e. the $5^{\text {th }}$ and $9^{\text {th }}$ week of plant age, three root samples from three randomized pots (one from each pot) were taken and the amount of salicylic acid in fresh roots was measured according to lqbal and Vaid (2009). Shoot and root dry 
weights $\mathrm{g} /$ plant were also recorded. Three pots per each treatment from the shoot were analyzed for the determination of $N$ by Nessler's method (Chapman and Pratt 1978), and P (Jackson 1973). The concentrations of K and $\mathrm{Na}$ were determined by flame photometry as described by Worth (1985). Carbohydrates and three amino acids; proline, arginine and phenylalanine were measured spectrophotometerically in root (Umbreit et al. 1972). At the end of the experiment soil's electrical conductivity (EC) from the different treatments was measured.

The experimental design consisted of $6(3 \times 4)$ treatments crossing three mycorrhizal inoculation levels (non-AMF, G.intraradices (G3) and $G$. intraradices (G4) with four salt levels ( $\mathrm{Na} \mathrm{Cl}$ ). Pots were arranged as factorial in a completely randomized block design. Six replicates of each treatment were applied totaling 24 pots for each AMF strain. The statistical analysis was done according to SAS (1989).

\section{RESULTS AND DISCUSSION}

\section{1- Measurement of soil electrical conductivity (EC)}

At the end of the experiment, soil samples from each treatment were randomized collected and the EC $\left(\mathrm{dSm}^{-1}\right)$ was measured. Figure (1) shows that the soil EC at the beginning of the experiment was $0.8 \mathrm{dSm}^{-1}$. In case of non-mycorrhizal plants the soil salinity was increased according to the irrigation of $\mathrm{NaCl}$ level. It reached $0.33,1.54,2.41$ and $3.54 \mathrm{dSm}^{-1}$ in treated plants with $0.4,2.0,4.0$ and $6 \mathrm{dSm}^{-1} \mathrm{NaCl}$ solution, respectively. Glomus intraradices $(G 3)$ reduced soil salinity within all salt concentrations by -41.6 , -24.5 and $-24.3 \%$ than the un-inoculated and irrigated plants with 2.0, 4.0 and $6.0 \mathrm{dSm}^{-1}$ respectively. G.4 had also a positive effect on soil EC and inoculated soil pots with $G .4$ reached $-31.8,-17.8$ and $-13 \%$ reduction than the un-inoculated ones in case of irrigated plants with 2.0, 4.0 and $6.0 \mathrm{dSm}^{-1}$, respectively.

\section{2- Na uptake in shoots (ppm)}

Figure (2) shows the significant effect of both AM strains on the reduction of $\mathrm{Na}$ uptake in shoots. $\mathrm{Na}$ uptake in shoots of non-AM maize seedlings was 10.6, 17.0, 22.6 and $32.3 \mathrm{ppm}$ in case of irrigated pots with tap water, 2.0, 4.0 and $6.0 \mathrm{dSm}^{-1}$ of $\mathrm{NaCl}$ solution. The percentage decrease of $\mathrm{Na}$ uptake in case of $G$. intraradices (G3) reached $50 \%$ when plants irrigated with moderate and high concentration of $\mathrm{Na} \mathrm{Cl}\left(4\right.$ and $\left.6 \mathrm{dSm}^{-1}\right)$ as compared to non -inoculated plants. G4 showed the same trend in Na uptake, but $\mathrm{Na}$ uptake was more reduced in G3 than G4. Similar results were obtained by $\mathrm{He}$ et al. (2010). One of the harmful effects of salinity on plant growth involves the excessive accumulation of $\mathrm{Na}^{+}$and $\mathrm{Cl}^{-}$(Ashraf and Hrris 2004 ; Munns et al. 2002). More $\mathrm{Na}^{+}$accumulation resulted in ionic imbalance, specific ion effects and nutrient deficiency symptoms in plants. They found that the $\mathrm{Na}^{+}$ concentration in shoots and roots of non - AM tomato seedlings was 1.11 and 1.22 times of AM plants respectively, under saltless condition, 1.57 and 1.26 times under $0.5 \%$ salt stress, 1.07 and 1.06 times under $1 \%$ salt stress respectively. They also reported that AM colonization seemed to decrease 
$\mathrm{Na}^{+}$under $0.5 \%$ salt stress, remarkably. Our results showed that $\mathrm{AM}$ helped to sustain ion balance and lower $\mathrm{Na}^{+}$accumulation which played key role in improving salt tolerance of AM maize.

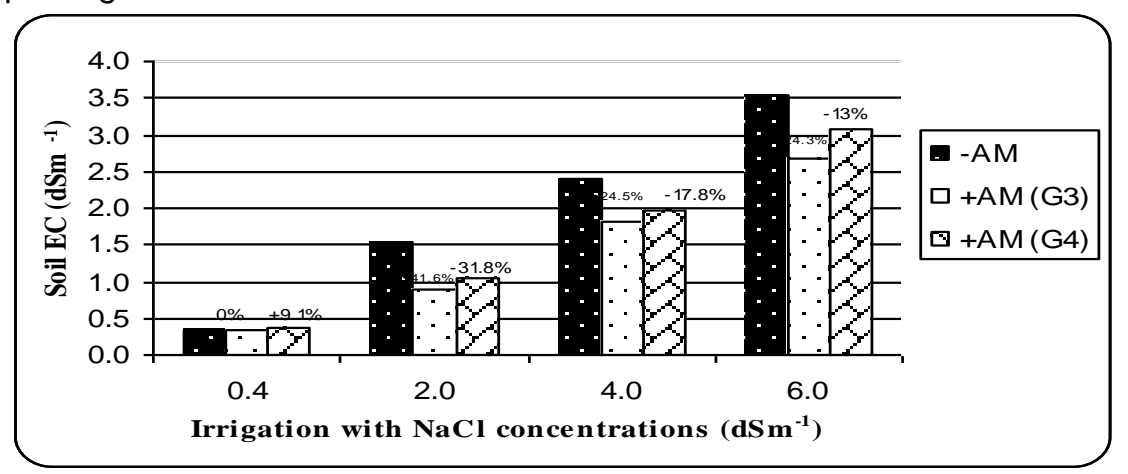

Figure (1). Soil EC $\left(\mathrm{dSm}^{-1}\right)$ at the end of maize experiment

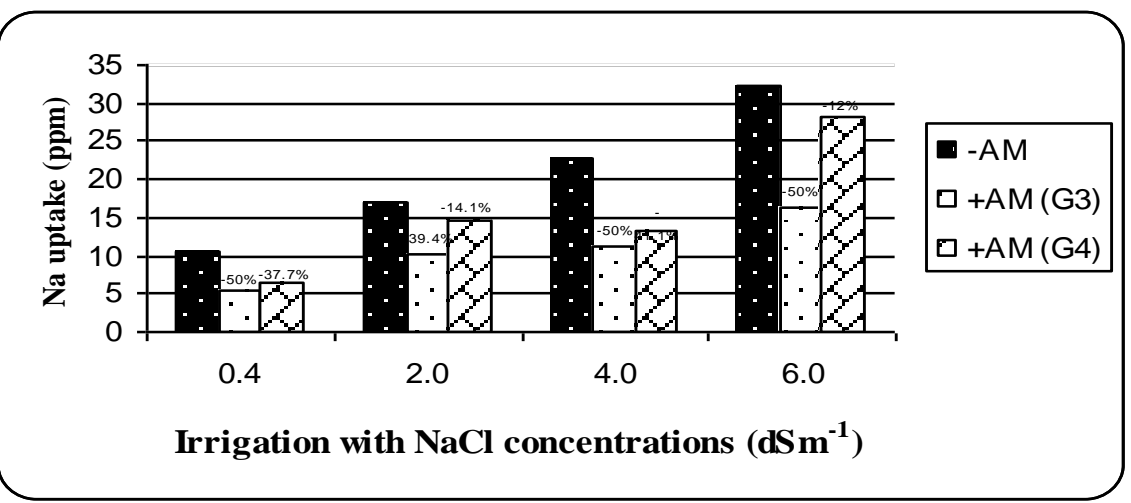

Figure (2). Effect of two strains of Glomus intraradices on Na uptake in maize shoots (ppm) under different $\mathrm{NaCl}$ stress

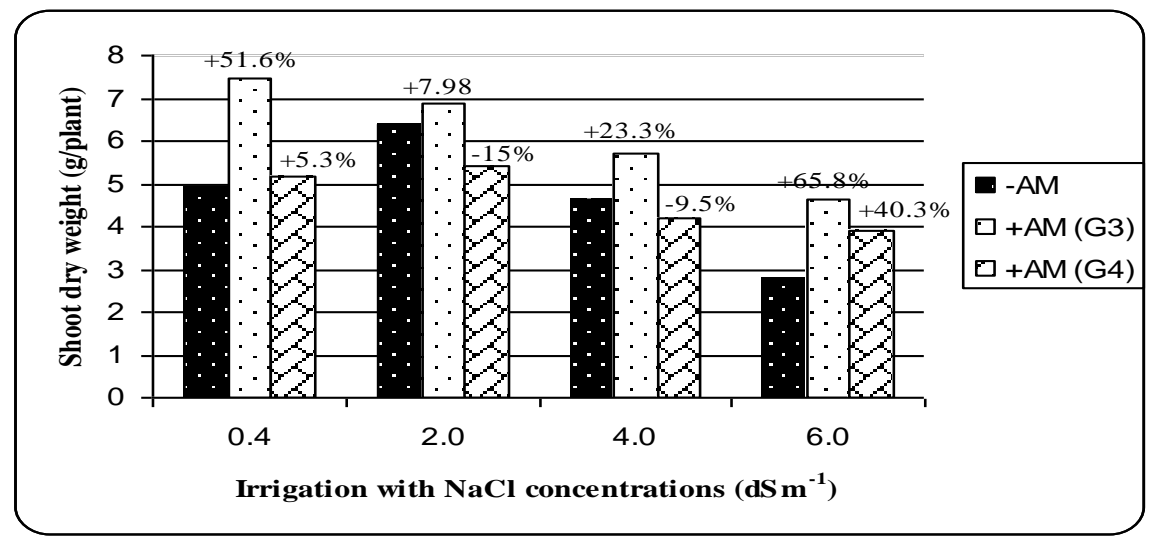

Figure (3). Effect of two strains of Glomus intraradices on shoot dry weight (g/plant) under different $\mathrm{NaCl}$ stress 


\section{3- Shoot and root dry weights (g / plant)}

$\mathrm{Na} \mathrm{Cl}$ stress significantly reduced plant growth (Figures 3 and 4). Shoot and root dry weights increasement were significantly larger than corresponding non-AM seedlings. The percentage increase in shoot dry weight in case of inoculated plants with G3 was 8, 23.3, 65.8\% more than un-inoculated ones under different salt level stress $\left(2,4\right.$ and $\left.6 \mathrm{dSm}^{-1}\right)$, respectively. Whereas the percentage increase was $39.3,66.2$ and $24.5 \%$, respectively, in root dry weight compared to non-AM. Inoculated plants with G4 increased the shoot dry weight in case of the highest concentration of $\mathrm{Na}$ $\mathrm{Cl}\left(6 \mathrm{dSm}^{-1}\right)$. The same trend was also found in root dry weight. Similar results were reported by Al-Karaki et al. (2001) and He et al. (2010).

\section{4- Salicylic acid (SA) (mg / 100g root fresh wt)}

Salicylic acid was measured spectrophotometricaly in maize fresh roots ( $\mathrm{mg} / 100 \mathrm{~g}$ fresh root). Data in Figures (5a and $5 \mathrm{~b}$ ) show the significant increase in salicylic acid's amount under the different levels of $\mathrm{Na} \mathrm{Cl}$, especially in inoculated plants either with G3 or G4 when plants were 5 and 9 weeks old. The highest percentage increase appeared in G3 at the end of the experiment. It reached 54,67 and $95.6 \%$ in the presence of 2, 4 and $6 \mathrm{dSm}^{-1}$, respectively, as compared to the un-inoculated plants. The same trend was shown in case of G4. Salicylic acid is a plant phenol, and it is in use as internal regulator hormone, because its role in the defensive mechanism against biotic and abiotic stresses (Shahba et al. 2010).

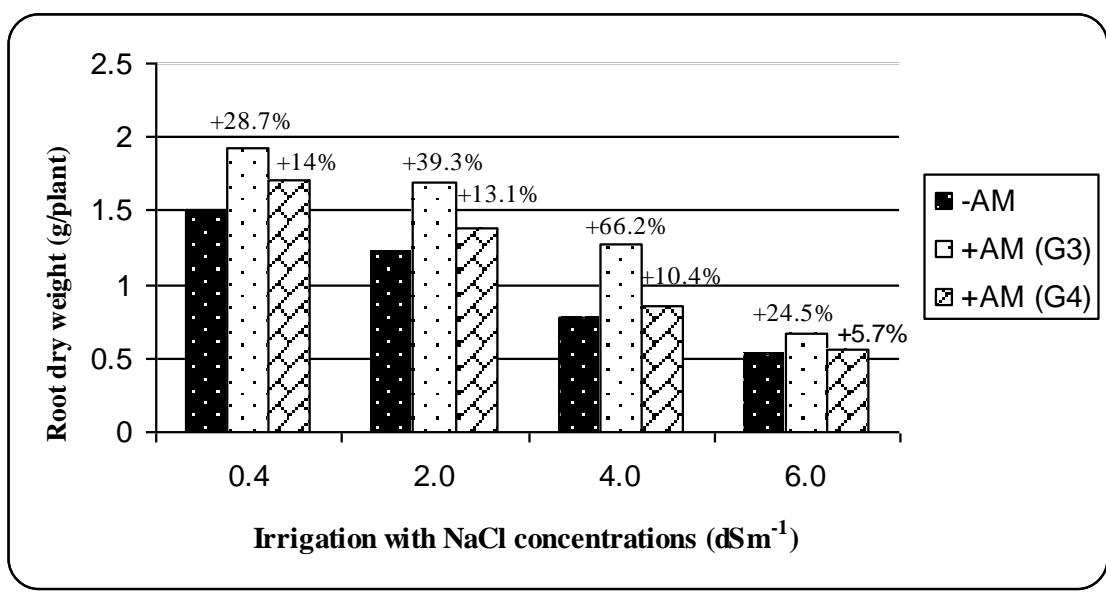

Figure (4). Effect of two strains of Glomus intraradices on root dry weight (g/plant) under different $\mathrm{NaCl}$ stress 

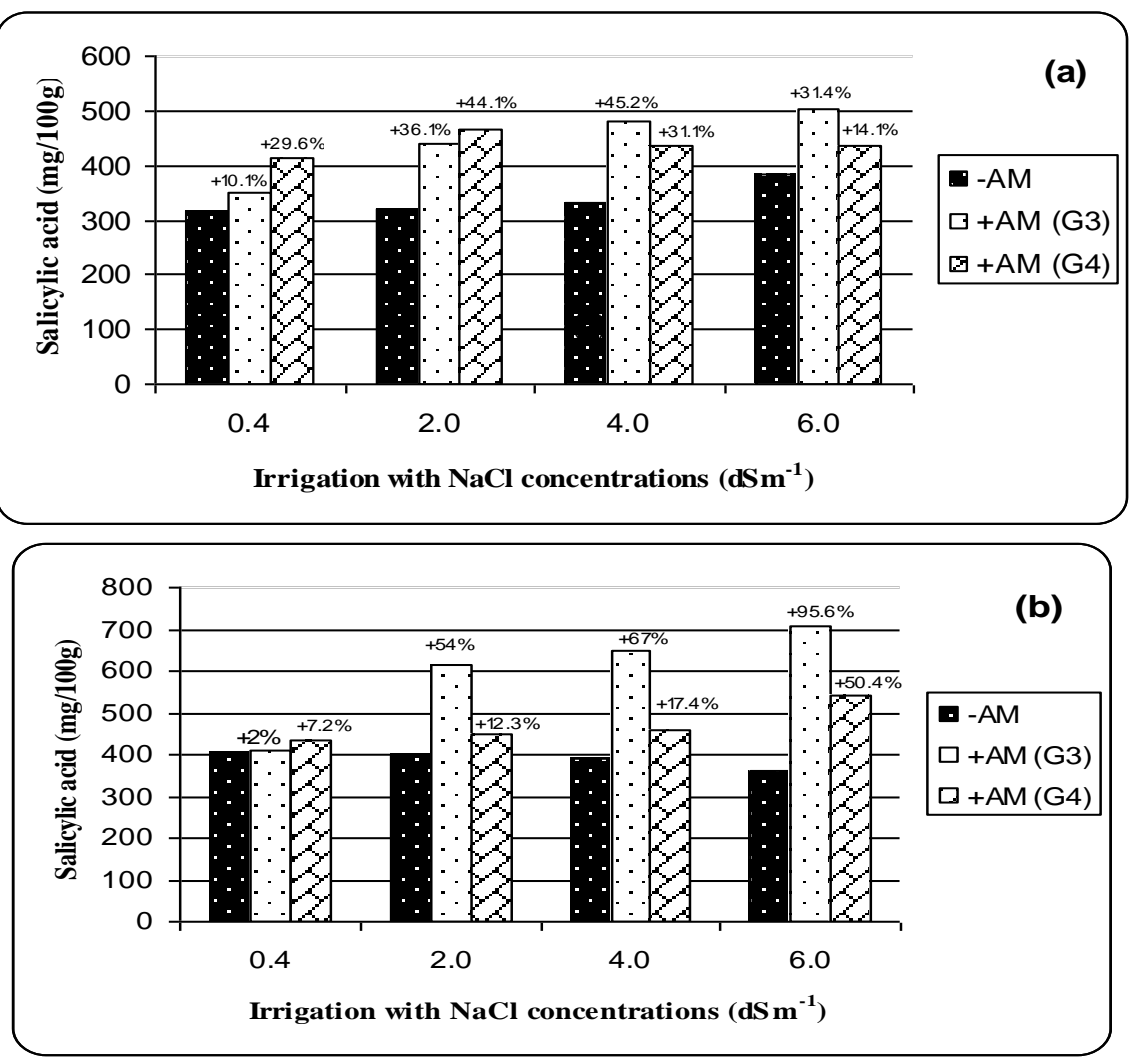

Figure (5). Effect of two strains of Glomus intraradices on salicylic acid content in root fresh weight $(\mathrm{mg} / 100 \mathrm{~g})$ under different $\mathrm{NaCl}$ stress a) after 5 weeks from planting b) after 9 weeks from planting

Klessig and Malamy (1994) and Clarke et al. (2000) reported that, salicylic acid (SA) has been firmly established as a natural signal molecule in the induction of systemic acquired resistance (SAR) in tobacco, cucumber and some other plants. Recent studies show that SA can enhance plant resistance to environmental stresses, such as heat, chilling and drought (Janda et al. 1999 and Tissa et al. 2000).

\section{5- Free amino acids}

Proline, arginine and phenylalanine were determined in maize roots. Figure (6) shows that with increasing salinity, the root proline increases. Significant increases were obtained in AM roots as compared to the uninoculated ones. The high amount of accumulated proline in roots was in case of G3 and G4 under 4 and $6 \mathrm{~d} \mathrm{Sm}^{-1}$.

Figures (7) and (8) show the amount of arginine and phenylalanine as compared to the un-inoculated plants. The plants under salinity condition change their metabolism to overcome the changed environmental condition. One mechanisms used by the plants for overcoming the salt stress effects 
might be via accumulation of compatible osmolytes, such as proline and soluble sugar. Production and accumulation of free amino acids, especially proline by plant tissue during drought, salt and water stress is an adaptive response. Proline has been proposed to act as a compatible solute that adjusts the osmotic potential in the cytoplasm, (Shahba et al. 2010 ; Ayala Astorga and Alcaraz - Meléndez 2010).

\section{6- Soluble sugar ( $\mathrm{mg} / 100 \mathrm{~g}$ root dry weight)}

Figure (9) shows carbohydrate content in maize roots ( $\mathrm{mg} / 100 \mathrm{~g}$ dry weight). Soluble sugar was increased in AM roots than corresponding non-AM under the different levels of $\mathrm{Na} \mathrm{Cl}$ stress. Under continuous salt stress, our results showed that the enhanced salt tolerance was closely related to the increase of soluble sugar accumulation in roots of AM plants. Results obtained by Feng et al. (2002) indicated that improved tolerance of maize plants to salt stress by arbuscular mycorrhiza was related to the higher accumulation of soluble sugars in roots. He et al. (2010) explained that the greatest sugar accumulation in AM plant under salt stress may be due to (1) the ability of plants to cope with salt stress, (2) the sink effect of the mycorrhizal fungus demanding sugars from shoot tissues, (3) the fact that AM colonization enhanced photosynthesis and therefore allowed higher allocation of sugars from leaves to roots Moreover, the salt stressed seedlings accumulated more total soluble carbohydrates in the roots than in the leaves, thus showing a change in behavior of shoot / root carbon partitioning. This probably reflects the maintenance or even induction of root elongation at low water potentials, which can be considered as an adaptive response to drought and salinity (Balibrea et al. 2000).

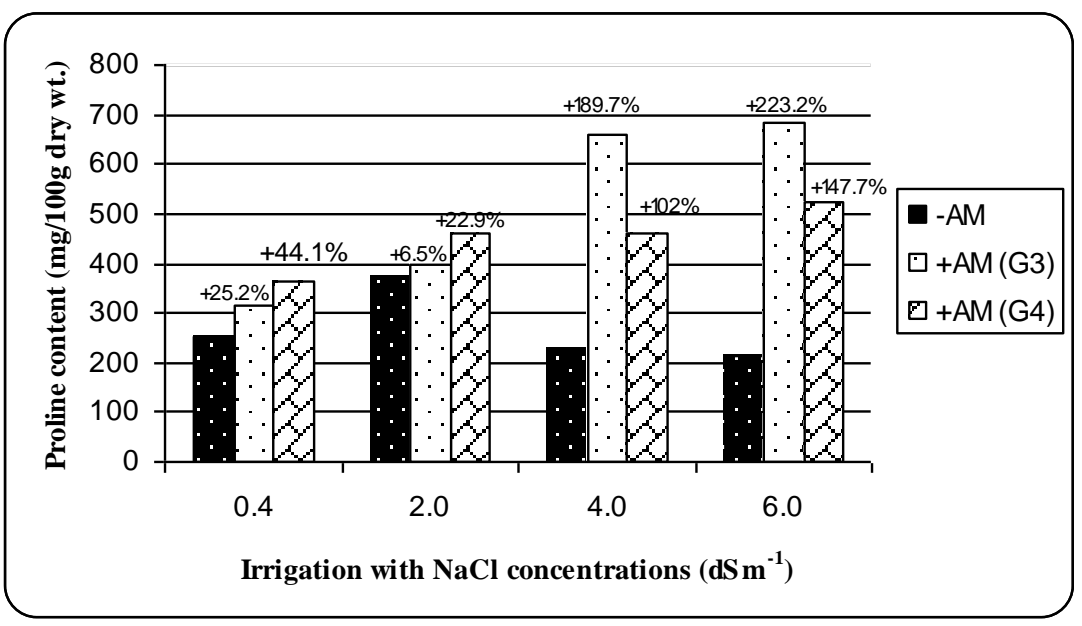

Figure (6). Effect of two strains of Glomus intraradices on proline content in root dry weight $(\mathrm{mg} / 100 \mathrm{~g})$ under different $\mathrm{NaCl}$ stress 


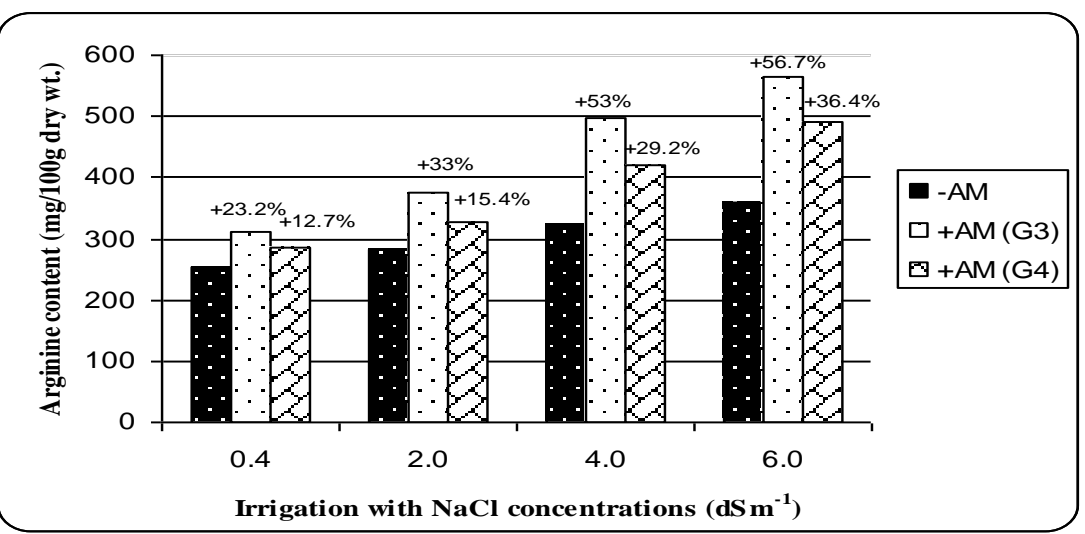

Figure (7). Effect of two strains of Glomus intraradices on arginine content in root dry weight $(\mathrm{mg} / \mathbf{1 0 0 g})$ under different $\mathrm{NaCl}$ stress

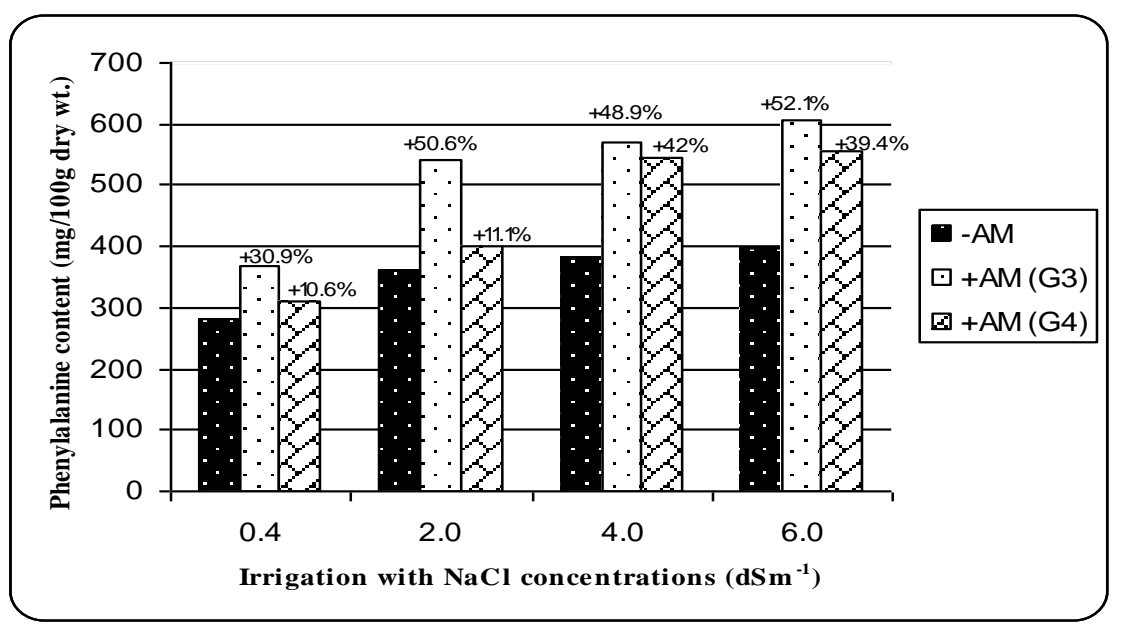

Figure (8). Effect of two strains of Glomus intraradices on phenylalanine content in root dry weight $(\mathbf{m g} / \mathbf{1 0 0 g})$ under different $\mathrm{NaCl}$ stress

\section{7- N P K uptake (mg /100g dry weight)}

N P K uptakes in maize shoots were determined at the end of the experiment under salt stress.

\section{a- $\mathrm{N}$ uptake:}

Figure (10) shows that AM inoculation significantly increased $\mathrm{N}$ uptake under the different levels of $\mathrm{NaCl}$ as compared to the non-inoculated plants. Studies have reported that improved $\mathrm{N}$ nutrition may help to reduce the toxic effects of $\mathrm{Na}$ ions by reducing its uptake and this may indirectly help in maintaining the chlorophyll content of the plant. The form of available $\mathrm{N} \mathrm{NO}_{3}^{-}$ or $\mathrm{NH}_{4}^{-}$) strongly influences $\mathrm{Na}^{+}$accumulation (Giri and Mukerji 
2004). However, the exact mechanisms used by AMF to $\mathrm{N}$ uptake under salt stress conditions are not clearly understood.

b- $P$ uptake (mg /100 dry weigh)

AMF have been shown to have a positive influence on the composition of mineral nutrients (especially poor mobility nutrients such as phosphorus) of plants grown in salt - stress conditions (Al- Karaki and Clark 1998).

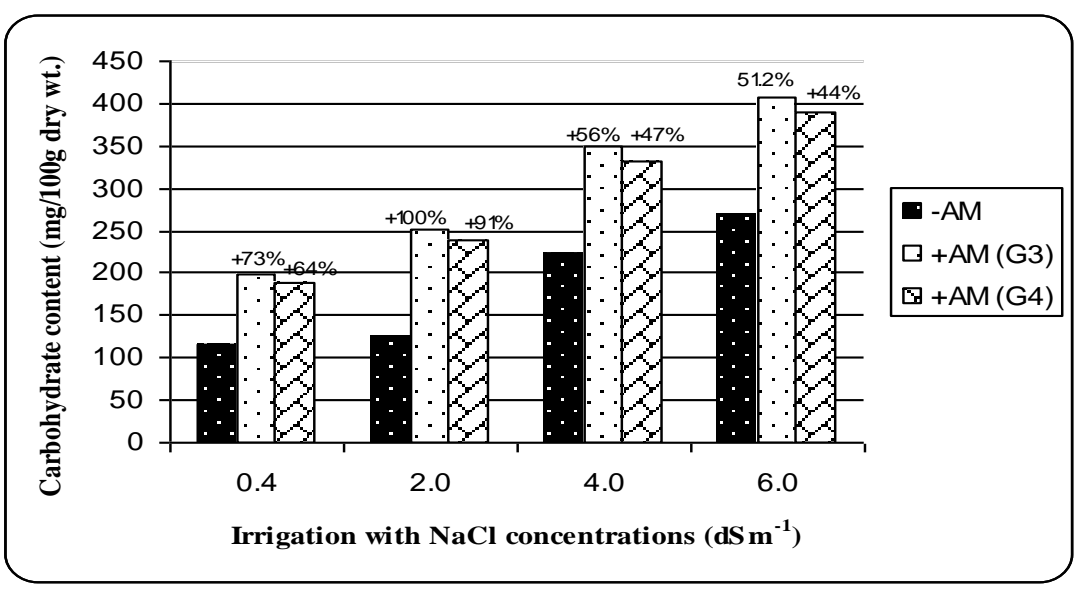

Figure (9). Effect of two strains of Glomus intraradices on carbohydrates content in root dry weight ( $\mathrm{mg} / 100 \mathrm{~g}$ dry wt.) under different $\mathrm{NaCl}$ stress

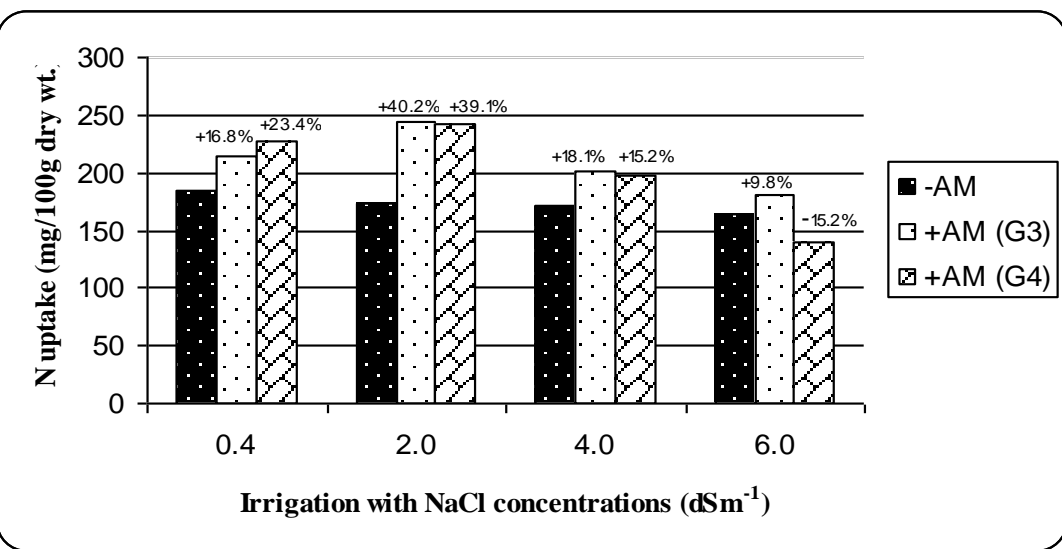

Figure (10). Effect of two strains of Glomus intraradices on N uptake ( $\mathrm{mg} / \mathbf{1 0 0 g}$ dry wt.) in shoot dry weight under different $\mathrm{NaCl}$ stress 


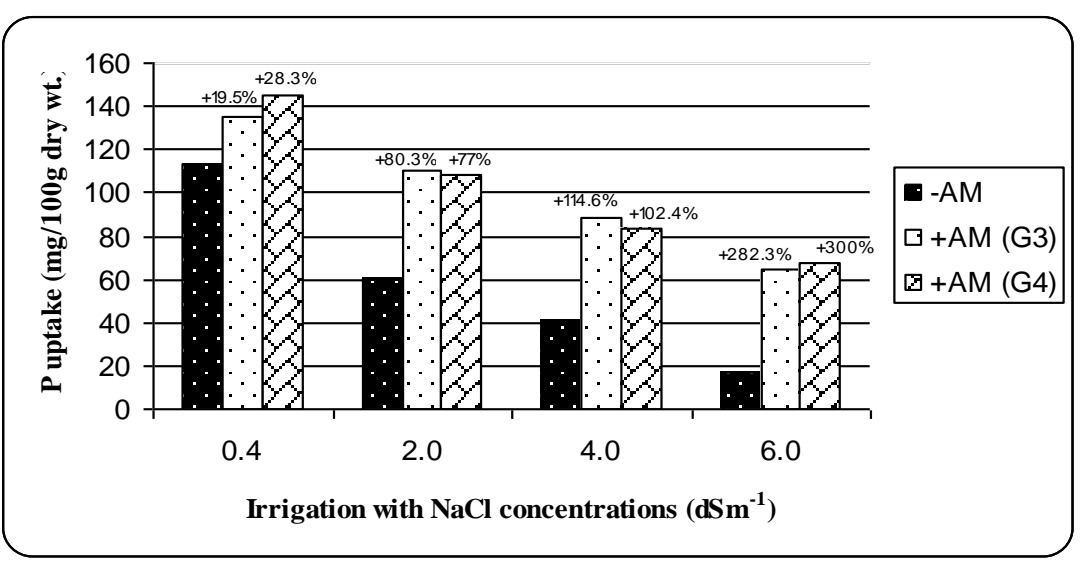

Figure (11). Effect of two strains of Glomus intraradices on P uptake ( $\mathrm{mg} / 100 \mathrm{~g}$ dry wt.) in shoot dry weight under different $\mathrm{NaCl}$ stress

Figure (11) shows that $A M$ inoculation resulted in highly significant increase of $P$ uptake as compared to the non-AM plants under all salt stress levels. The percentage was increased in case of G3 and G4 by increasing Na $\mathrm{Cl}$ level compared to non-inoculated maize plants. At salt level $4 \mathrm{dSm}^{-1} \mathrm{P}$ uptake was increased to 114.6 and $102.4 \%$ in case of G3 and G4, respectively, more than non-inoculated ones. Whereas the percentage increase of $P$ uptake reached 282.3 and $300 \%$ more than the non-inoculated plants for the same AM strains, respectively. Mycorrhizal inoculation can increase $\mathrm{P}$ concentration in plants by enhancing its uptake facilitated by the extensive hyphae of the fungus which allows them to explore more soil volume than the non-mycorrhizal plants (Ruiz - Lozano and Azcon 2000). It is estimated that external hyphae deliver up to $80 \%$ of a plant's $\mathrm{P}$ requirements (Matamores et al. 1999). Studies have shown higher $P$ content in mycorrhizal than non-mycorrhizal Acacia nilotica plants in saline soils at varied levels of soil salinity (Giri et al. 2007).

\section{c- K uptake (mg / 100g dry wt)}

Data in Table (1) shows the effect of $G$. intraradices on $\mathrm{K}$ uptake in maize shoots under $\mathrm{Na} \mathrm{Cl}$ stress. No significant differences were found due to $\mathrm{AM}$ inoculation. When $\mathrm{Na}^{+}$or salt concentration in the soil is high, plants tend to take up more $\mathrm{Na}^{+}$resulting in decreased $\mathrm{K}^{+}$uptake. $\mathrm{Na}^{+}$ions compete with $\mathrm{K}^{+}$ for binding sites essential for various cellular functions. Potassium plays a key role in plant metabolism. It activates a range of enzymes, and plays an important role in stomatal movements and protein synthesis (Blaha et al. 2000).

Zuccarini and Okurowska (2008) reported that mycorrhizal colonization can enhance $\mathrm{K}^{+}$absorption under saline conditions, while preventing $\mathrm{Na}^{+}$ translocation to shoot tissues. There are contrasting reports that the uptake of $\mathrm{K}^{+}$increased in shoot tissues of mycorrhizal plants even at a high salinity level $\left(9.5 \mathrm{dSm}^{-1}\right)$. This increases the $\mathrm{K}^{+}: \mathrm{Na}^{-}$ratio in roots and shoots of $\mathrm{AM}$ plants (Giri et al. 2007). 
Table (1). Effect of two strains of Glomus intraradices on K uptake ( $\mathrm{mg} / 100 \mathrm{~g}$ dry wt.) in shoot dry weight under different $\mathrm{NaCl}$ stress

\begin{tabular}{|c|c|c|c|c|c|c|c|c|}
\hline \multirow{3}{*}{\begin{tabular}{|l} 
Parameter \\
$\mathrm{NaCl}\left(\mathrm{dSm}^{-1}\right)$ \\
Inoculation
\end{tabular}} & \multicolumn{8}{|c|}{ K uptake (mg/100g shoot dry weight) } \\
\hline & \multicolumn{2}{|l|}{0.4} & \multicolumn{2}{|c|}{2.0} & \multicolumn{2}{|l|}{4.0} & \multicolumn{2}{|c|}{6.0} \\
\hline & $\mathrm{mg} / 100 \mathrm{~g}$ & $\pm \%$ & $\mathrm{mg} / 100 \mathrm{~g}$ & $\pm \%$ & $\mathrm{Mg} / 100 \mathrm{~g}$ & $\pm \%$ & $\mathrm{mg} / 100 \mathrm{~g}$ & $\pm \%$ \\
\hline$-\mathrm{AM}$ & $1361 \mathrm{a}$ & -- & $1828 \mathrm{a}$ & -- & $1618 \mathrm{a}$ & -- & $1152 \mathrm{a}$ & -- \\
\hline$+\mathrm{AM}(\mathrm{G} 3)$ & $1592 \mathrm{a}$ & +17 & $1642 \mathrm{a}$ & -10 & $1603 \mathrm{a}$ & -1 & $1383 a$ & +20 \\
\hline$+\mathrm{AM}(\mathrm{G} 4)$ & $1488 \mathrm{a}$ & +9.3 & $1772 \mathrm{a}$ & -3 & $1521 \mathrm{a}$ & -6 & $1207 \mathrm{a}$ & +4.8 \\
\hline Inoculation L.S.D. ${ }_{0.01}$ & \multicolumn{8}{|c|}{315.312 (ns) } \\
\hline Salinity L.S.D. 0.01 & \multicolumn{8}{|l|}{$364.091^{\star *}$} \\
\hline Interaction L.S.D. 0.01 & \multicolumn{8}{|c|}{$630.64(\mathrm{~ns})$} \\
\hline
\end{tabular}

\section{Conclusion:}

The role of arbuscular mycorrhizal fungi (AMF) in alleviation salt stress is well documented. Our study explained some mechanisms of AMF employ to enhance the salt tolerance of maize plants such as enhanced nutrient acquisition $(P, N)$, reduced $\mathrm{Na}^{+}$, biochemical changes (accumulation of proline and carbohydrates) and enhanced plants resistance to salt stress by increasing the amount of salicylic acid which has been proposed as an internal regular plant hormone.

\section{Acknowledgements:}

This research was supported by El-Fourat University, Syria. The authors express sincere thanks to Mr. El-Habbab for statistical analysis.

\section{REFERENCES}

Aboul-Nasr, A. (1993a). Identification of VA- mycorrhizal fungi in soil of Alexandria Governorate. Alex. J. Agric. Res. 38(2): 371-376.

Aboul-Nasr,A. (2004). Method of producing an inoculum of endomycorrhizal fungi. Academy Sci. Res. And Tech. Egypt. Patent No. 23234.

Adiku,G., Renger,M., Wessolek,G., Facklam,M. and Hech-Bischoltz,C. (2001). Simulation of dry matter production and seed yield of common beans under varying soil water and salinity conditions. Agric. water Management 47:55-68.

Al-Karaki,G.N. and Al-Raddad,A. (1997). Effect of arbuscular mycorrhizal fungi and drought stress on growth and nutrient uptake of two wheat genotypes differing in drought resistance. Mycorrhiza 7:83-88.

Al- Karaki,G.N. and Clark,R.B. (1998). Growth, mineral acquisition and water use by mycorrhizal wheat grown under water stress. J. of Plant Nutri. 21: 263-276.

Al-Karaki,G.N. (2000). Growth of mycorrhizal tomato and mineral acquisition under salt stress. Mycorrhiza 10: 51-54.

AL-Karaki,G.N. (2006). Nursery inoculation of tomato with arbuscular mycorrhizal fungi and subsequent performance. Scientia Horti. 109: 17. 
Al-Karaki,G.N., Hammad,R. and Rusan,M. (2001). Response of two tomato cultivars differing in salt tolerance to inoculation with mycorrhizal fungi under salt stress. Mycorrhiza 11: 43-47.

Ashraf,M. and Harris,P.J.C. (2004). Potential biochemical indicators of salinity tolerance in plants. Plant Sci. 166: 13-16.

Ayala-Astorga,G.I. and Alcaraz - Meléndez,L. (2010). Salinity effects on protein content, lipid peroxidation, pigments, and proline in Paulownia imperialis (Siebold \& Zuccarini) and Paulawnia fortunei (Seemann \& Hemsley) grown in vitro Environmental Biotechnology 13(5): 1-11.

Balibrea,M.E., Dell' Amico,J., Bolarin,M.C. and Perez-Alfocea,F.(2000). Carbon partitioning and sucrose metabolism in tomato plants growing under salinity. Physiol. Plant 110: 503-511.

Blaha,G., Stelzl,U., Spahn,C.M.T., Agrawal,R.K., Frank,J. and Nierhaus, K.H.(2000). Preparation of functional ribosomal complexes and effect of buffer conditions on t RNA positions observed by cryoelectron microscopy. Methods in Enzymology 317: 292-309.

Chapman,H.D. and Pratt,P.F.(1978). Methods of analysis for soil, plant and waters. Univ of California, Div Agri Sci, Priced publication 4043.

Clarke,J.D., Vilko,S.M., Ledford,H., Ausubel,F.M. and Dong,X.(2000). Roles of salicylic acid, jasmonic acid, and ethylene in cpr-induced resistance in Arabidopsis. Plant Cell 12: 2175-2190.

Copeman,R.H., Martin,C.A., and Jtutz,J.C.(1996). Tomato growth in response to salinity and mycorrhizal fungi from saline or nonsaline soils. Horti. Sci. 31: 341-344.

Creus CM, Sueldo,R.J. and Barassi,C.A.(1998). Water relations in Azospirillum inoculated wheat seedlings under osmotic stress. Canadian J. of Botany 76:238-244.

Dehne,H.W. (1982). Interaction between vesicular-arbuscular mycorrhizal fungi and plant pathogens. Phytopathology 72: 1115-1119.

Feng,G., Zhang,F.S., Li,X.L., Tian,G.Y., Tang,C. and Rengel,Z.(2002). Improved tolerance of maize plants to salt stress by arbuscular mycorrhiza is related to higher accumulation of soluble sugars in roots. Mycorrhiza 12:185-190.

Giri,B.and Mukerji,K.G.(2004). Mycorrhizal inoculant alleviates salt stress in sesbania aegyptiaca and Sesbania grandiflora under field conditions: evidence for reduced sodium and improved magnesium uptake. Mycorrhiza 14: 307-312.

Giri,B., Kapoor,R. and Mukerji,K.G.(2007). Improved tolerance of Acacia nilotica to salt stress by arbuscular mycorrhiza, Glomus fasciculatum, may be partly related to elevated $\mathrm{K}^{+} / \mathrm{Na}^{+}$ratios in root and shoot tissues. Microbial Ecology 54: 753-760.

He,Z.Q.,Tang,H.R., Li,H.X., He,C.X., Zhang,Z.B. and Wang,H.S.(2010).

Arbuscular mycorrhizal alleviated ion toxicity, oxidative damage and enhanced osmotic adjustment in tomato subjected to $\mathrm{Na} \mathrm{Cl}$ stress. American- Eurasian J. Agric Environ Sci. 7(6): 676-683.

lqbal,A. and Vaid,F.(2009). Determination of benzoic acid and salicylic acid in commercial Benzoic and salicylic acid ointments by spectrophotometer method. Pak J. Pharm. Sci. 22: 18-22. 
Jackson,M.L.(1973). Soil chemical analysis constable and Co LTD. London.

Jahromi,F., Aroca,R., Porcel,R. and Ruiz - Lozano,J.M. (2008). Influence of salinity on the in vitro development of Glomus intrardices and on the in vivo physiological and molecular responses of mycorrhizal lettuce plants. Microbial Ecology 55:45-53.

Janda,J., Szalai,G., Tari,I. and Paldi,E.(1999). Hydropnic treatment with salicylic acid decreases the effects of chilling injury in maize (Zea mays L.) plants. Planta 208: 175-180.

Juniper,S. and Abbott,L.K.(1993). Vesicular arbuscular mycorrhizas and soil salinity. Mycorrhiza 4: 45-57.

Klessig,D.F. and Malamy,J.(1994). The salicylic acid signal in plants. Plant Mol Biol. 26: 1439-1458.

Lindermann,R.G.(1994). Role of VAM in bios control. In: Pfleger FL, Linderman RG editors. Mycorrhizae and plant health. St Paul: American phytopathological Society. p. 1-26.

Matamoros,M.A., Baird,L.M. and Escuredo,P.R.(1999). Stress-induced legume root nodule senescence: physiological biochemical and structural alterations. Plant Physiol. 121:97-111.

Mouk,B.O. and Ishii,T.(2006). Effect of arbusculer mycorrhizal fungi on tree growth and nutrient uptake of Sclerocarya birrea under water stress, salt stress and flooding. $J$ of the Japanese Society for Horti.Sci. 75: 2631.

Munns,R., Hussain,S., Rivelli,A.R., James,R.A. and Condon,A.G.(2002). A venues for increasing salt tolerance of crops and the role of physiologically based selection traits. Plant Soil 247: 93-105.

Ruiz- Lozano,J.M. and Azcon,R.(2000). Symbiotic effeiciency and infectivity of an autochthonous arbuscular mycorrhizal Glomus sp. from saline soils and Glomus deserticola under salinity. My- corrhiza 10: 137-143.

Ruiz-Lozano,J.M., Collados,C., Barea,J.M. and Azcón,R.(2001). Arbuscular mycorrhizal symbiosis can alleviate drought induced nodule senescence in soybean plants. Plant physiol. 82: 346-350.

SAS, Institute (1989). SAS User's Guide: Statistics version $6.4^{\text {th }}$ Ed., Vol. 2.p. 956 SAS Institute Inc. Cary NC.

Shahba,Z., Baghizadeh,A., Vakili,S.M.A., Yazdanpanah,A. and Yosefi, M.(2010). The salicylic acid effect on the tomato (Lycopersicum esculentum Mill.) sugar, protein and proline contents under salinity stress ( $\mathrm{Na} \mathrm{Cl})$. J of Biophysics and structural Biology 2(3): 35-41.

Smith,S.E. and Read,D.J. (1995). Mycorrhizal Symbiosis. Academic Press, New york, NY: 105-160.

Smith,S.E. and Read,D.J.(1997). Mycorrhizal symbiosis. Academic Press, San Diego and London. 125-136.

Tissa,S., Darren,T., Eric,B. and Kingsley,D.(2000). Acetyl salicylic acid (aspirin) and salicylic acid induce multiple stress tolerance in bean and tomato plants. Plant Growth Reg. 30: 157-161.

Umbreit,W.W., Burris,R.H. and Stauffer,J.F.(1972). Manometric and biochemical techniques. Burgess publishing company. 
Wang,W., Vinocur,B., Altman,A.(2003). Plant responses to drought salinity and extreme temperature toward genetic engineering for stress tolerance. Planta $218: 1-14$

Worth,H.G.(1985). A comparison of the measurement sodium and potassium by flame photometer and ion-selectve electrode. Ann Clin Biochem. 22: 343-350.

Zuccarini,P. and Okurowska,P.(2008). Effects of mycorrhizal colonization and fertilization on growth and photosynthesis of sweet basil under salt tress. J. of plant Nutri. 31: 497-513.

تـأثير الميكـوريزا الاخليـة علـي نباتـات الـذرة تحت تـأثير مسـتويات مختلفـة مسن

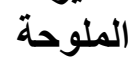
أمال أبو النصر 1 و علي أمرير2

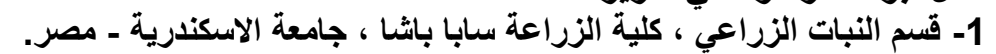
2- قسم الأراضي واستصلاح الأراضي ، كلية الزراعة ، جامعة الزعة الفرات ـ سوريا.

أجريت التجربة في صوبه زجاجية لدراسة تأثير عزلتين من فطر الميكوريزا الداخلية

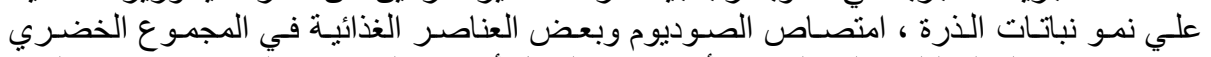

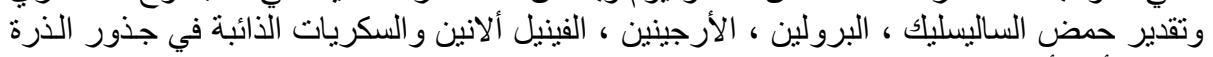

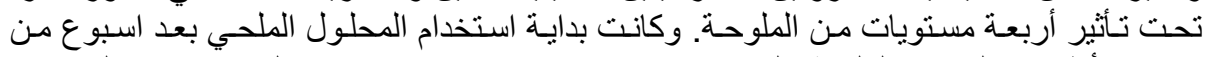

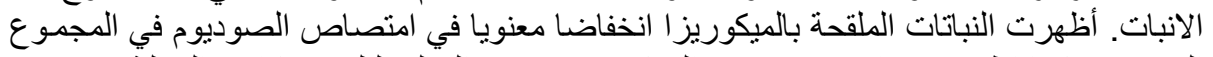

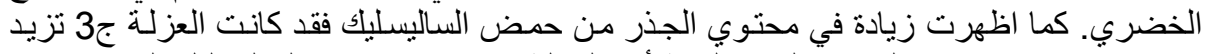

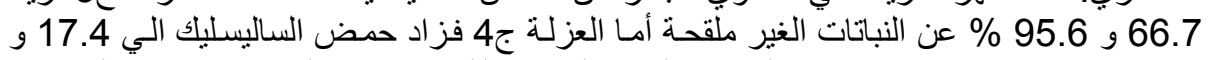

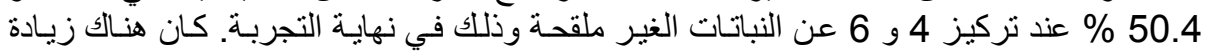

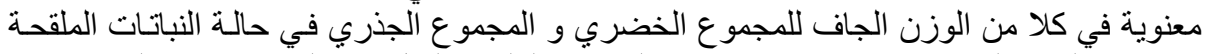

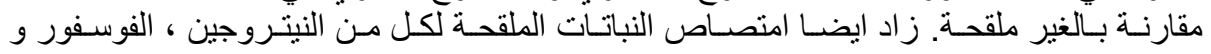

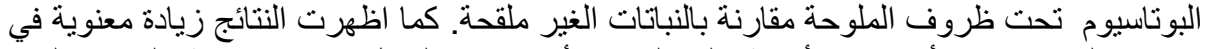

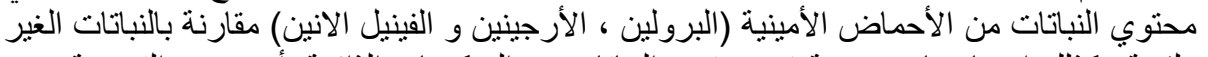

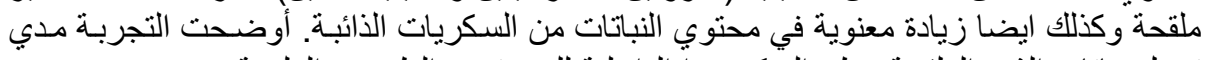

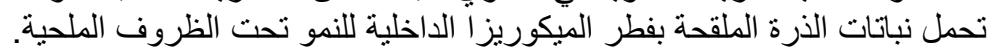

كلية الزراعة - جامعة المنصورة

كلية الزراعة - جامعة المنصورة

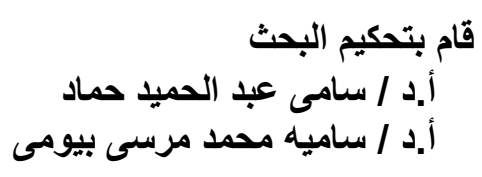

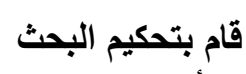

أ.د / سماميه محمد مرسى بيومى عماد الدمى 